\title{
Pluralismo religioso e diálogo inter-religioso: o lugar do sujeito nesse processo
}

\section{Religious pluralism and interreligious dialogue: the place of the subject in this process}

\section{Pluralismo religioso y diálogo inter-religioso: el lugar del sujeto en este procedimiento}

\author{
Alonso S. Gonçalves*
}

\begin{abstract}
RESUMO
Esse texto procura pensar a relação entre pluralismo religioso, diálogo inter-religioso e o conceito de sujeito desenvolvido por Alain Touraine. A partir de uma possibilidade em que, por um lado, há uma constatação da crise das instituições que operacionalizam a religião e, por outro, o pluralismo religioso é um fato, procuraremos alocar o diálogo inter-religioso nesse contexto. Uma vez estabelecida esta situação, o texto se ocupará em trabalhar os anseios do diálogo inter-religioso tendo a dimensão ética como caminho e, com isso, espera-se contribuir para uma leitura do contexto religioso e as possibilidades de interação a partir da noção de sujeito.

Palavras-chave: Pluralismo Religioso; diálogo inter-religioso; sujeito.
\end{abstract}

\begin{abstract}
This text tries to think about the relation between religious pluralism, inter-faith dialogue and the concept of subject developed by Alain Touraine. From a possibility in which, on the one hand, there is a crisis of institutions that operationalize religion, and on the other, religious pluralism is a fact, we will try to allocate interreligious dialogue in this context. Once the situation has been established, the text will focus on working the anxieties of interreligious dialogue, having the ethical dimension as a way and with this, it is hoped to contribute to a reading of the religious context and the possibilities of interaction from the notion of subject.

Keywords: Religious pluralism; interreligious dialogue; subject.

\section{RESUMEN}

Este texto busca pensar la relación entre pluralismo religioso, diálogo interreligioso y el concepto de sujeto desarrollado por Alain Touraine. A partir de una posibilidad en que, por un lado, hay una constatación de la crisis de las instituciones que operan la religión, y por otro el pluralismo religioso es un hecho, procuraremos asignar el diálogo interreligioso en ese contexto. Una vez colocada la situación, el texto se ocupará en trabajar los anhelos del diálogo interreligioso teniendo la dimensión ética como camino y con ello, se espera contribuir a una lectura del contexto religioso y las posibilidades de interacción a partir de la noción de sujeto .

Palabras clave: Pluralismo religioso; diálogo inter-religioso; sujeto.
\end{abstract}

Doutorando em Ciências da Religião na Universidade Metodista de São Paulo, licenciatura em Filosofia (2006).alonso3134@hotmail.com 


\section{Primeiras considerações}

Esse texto procura pensar a relação entre pluralismo religioso, diálogo inter-religioso e o conceito de sujeito desenvolvido por Alain Touraine, pensador francês. Para o que se propõe, algumas constatações se mostram imprescindíveis, dentro de um cenário religioso que passa por descolamentos de sentido, quando as instituições que administram o sagrado vêm enfrentando concorrentes que operam na produção de sentido, não sendo, precisamente, religioso, mas exercendo fascínio e adesão como se religião fosse. Assim, as religiões se dão dentro de um universo plural, não apenas entre as religiões que são, per si, plurais, como também na pluralidade de oferta de sentido, configurando como uma, dentre outras, possibilidades na oferta de bens simbólicos.

Ao que parece, segundo Faustino Teixeira, "não há como negar, no tempo atual, a presença de uma crise nas instituições religiosas tradicionais, e de modo muito particular no cristianismo" (2015, p. 362). As razões para essa crise se encontram na “crescente 'desinstitucionalização' da religião no tempo atual” (TEIXEIRA, 2015, p. 362). Esse dado tem como característica desinstitucionalizar as práticas religiosas, favorecendo a fluidez das dinâmicas espirituais, quebrando, assim, “o monolitismo de tradições que se apresentam como imutáveis, firmadas em dispositivos institucionais normativos e rígidos" (TEIXEIRA, 2015, p. 367). Nesse sentido, o pluralismo se constitui como um fato dado e insuperável. Como um corolário da modernidade, a secularização favoreceu o pluralismo religioso, e este passou a ser um tema necessário para se entender o atual momento das tradições religiosas a partir de um mundo que passou pelo processo do desencantamento (Weber). Esse processo, a nosso ver, contribuiu para que um pluralismo de sentido se estabelecesse, destronando, assim, o monopólio das religiões tradicionais, mais especificamente o cristianismo no Ocidente.

Aqui, procuraremos responder algumas perguntas:

1. É possível, a partir de uma constatação da crise das instituições que operacionalizam a religião, e tendo o pluralismo religioso como um fato, haver possibilidades de diálogo inter-religioso?

2. Havendo essa possibilidade, como se daria esse diálogo, uma vez que as principais preocupações do humano se dão no aspecto subjetivo?

3. Se for possível apontar um caminho, a concepção de sujeito, desenvolvida por Alain Touraine, poderia iluminar esse trajeto?

Assim, esperamos contribuir para uma leitura do contexto religioso e as possibilidades de interação. Mas, antes dessa tentativa, é importante fincar algumas bases teóricas para o que se propõe. 


\section{Religião, secularização e instituição}

Embora o conceito de secularização seja polissêmico, ainda se constitui como termo para explicar as consequências da modernidade para a religião. Com a modernidade, a religião deixa de ser protagonista e passa a ser coadjuvante. Peter L. Berger, por exemplo, chama esse processo de "crise de credibilidade" (1985, p. 139). Essa "crise" é consequência do "efeito da secularização para o homem comum", ou seja, a "secularização acarretou um amplo colapso da plausibilidade das definições religiosas tradicionais" (BERGER, 1985, p. 139). Outrora, a religião exercia uma função integradora na sociedade e manuseava os símbolos religiosos como legitimadora de uma ordem social e política (LIBÂNIO, 2002, p. 123); com a modernidade, esse quadro muda radicalmente e o que era sólido se derrete. "A modernidade atinge precisamente esses sistemas simbólicos religiosos, criando outros sistemas de significado de natureza secular" (LIBÂNIO, 2002, p. 123). Esse processo culmina com o aparecimento do Estado, dentre outros elementos, constituindo, assim, como um fator decisivo para o que Berger chamou de "crise de credibilidade". Deste modo, é o Estado que passa a assumir "a função estruturadora da sociedade" (BARRERA RIVERA, 2001, p. 99), e não mais a religião. Embora o paradigma tenha mudado, como atesta Alain Touraine, da religião (Igreja) para a política (Estado), da política para a economia (capital), onde o Estado, agora, está à serviço deste último (2007, p. 9).

Mesmo com essas mudanças, é consenso entre os pesquisadores que a religião nunca deixou - como alguns profeticamente propagaram - de ocupar o seu espaço no contexto social. A expressão "retorno do sagrado" se dá de maneira imprópria, uma vez que o sagrado nunca ficou ausente da realidade humana. A secularização não significa ausência da religião na sociedade, ou seja, a secularização não pode ser concebida como uma retirada da religião da vida, mesmo com o aparecimento do Estado. Antes, em "Estados modernos mais desenvolvidos, a religião não foi completamente relegada à vida privada, nem tampouco perdeu toda capacidade de influir na sociedade" (BARRERA RIVERA, 2001, p. 113). Assim, acompanhando Paulo Barrera Rivera, a secularização significou "o enfraquecimento da influência social e do poder político da instituição religiosa", ou seja, acelerou a "liberação da sociedade do controle institucional da religião" (2001, p. 113). Dito de outro modo, a secularização não anula o sentido religioso. Antes, antagoniza o sagrado com as instituições, outrora legitimadoras do primeiro, quando detinham o monopólio dos símbolos religiosos e os manuseavam de maneira tutelar. Ao que parece, mesmo com nuances, esse quadro não ficou restrito à Europa. Na América Latina, há uma discussão quanto às reverberações da secularização e 
seu impacto na religião. Mesmo concordando que há diferenças expressivas quando se compara com contexto europeu, não há como negar as consequências da secularização na realidade latino-americana, principalmente quando se entende secularização como superação do controle social e político da religião (BARRERA RIVERA, 2001, p. 114-117).

Um dos principais efeitos da secularização é o processo da desinstitucionalização da religião. Isso não significa que não haja mais instituição operacionalizando o sagrado. Há, mas não detém o controle do sagrado como outrora. Quando Marcel Gauchet desenvolve o seu conceito de "saída da religião", ele trata da perda estrutural da religião, ou seja, se antes a religião funcionou como fator estruturante da vida material, social e mental, agora "não sobram mais que experiências singulares e sistemas de convicções" (LIBÂNIO, 2002, p. 133). A modernidade é a responsável pela "saída da religião", mas não do sentido religioso. Como bem observa Barrera Rivera, o conceito de "saída da religião" em Gauchet não significa a extinção da crença religiosa. Antes, é a transformação da religião (2001, p. 122). Quando Henrique Lott analisa o pensamento de Gauchet, ele conclui que, para o pensador francês, o "desencantamento do mundo, ou saída da religião, está diretamente ligado com o aparecimento da forma autônoma de gerenciamento do político que irá concretizar o caminho moderno" (2016, p. 161). Essa autonomia se contrapõe à heteronomia no pensamento de Gauchet. Mesmo sendo a religião ligada à heteronomia, não significa uma condição "antirreligiosa": "Para o filósofo francês, a religião é essencialmente heteronomia. No entanto, essa definição postula um enfoque político da religião" (LOTT, 2016, p. 161). Essa transformação se dá nas categorias em que a religião passa a operar, não mais exclusivamente por meio da instituição no seu sentido político e social. Se, antes, a instituição funcionava como casulo da religião, agora há uma "saída da religião" e o cristianismo é corresponsável por isso, porque "é a única religião compatível, até o extremo, com a modernidade" (LIBÂNIO, 2002, p. 132).

A modernidade favoreceu o pluralismo religioso, principalmente quando tornou a religião uma opção dentre outras. Quando a religião perdeu a sua institucionalidade, abriram-se possibilidades de outras formas de experiências religiosas que não são, necessariamente, mediadas pelas instituições religiosas tradicionais. Essa oferta de experiências religiosas desvinculadas da instituição estabelece, significativamente, um fundamento irrevogável do pluralismo religioso. Isso ocorre porque o sagrado está solto, "entregue às vivências pessoais, individuais em processo crescente de privatização e individualização" (LIBÂNIO, 1998, p. 61). A Igreja, de uma maneira geral, "sofreu" com a 
modernidade. Em especial a Igreja Católica, que perdeu força teológica com a Reforma Protestante, passando a disputar o que considerava hegemônico: a fé. Em sequência, a Revolução Francesa desferiu um duro golpe no domínio político e ideológico da Igreja (SANCHEZ, 2005, p. 30-31). Esses dois acontecimentos contribuíram para o pluralismo. $\mathrm{O}$ mundo não seria mais $\mathrm{O}$ mesmo e, muito menos, igual. O Estado toma a forma de "religião", principalmente quando a sua principal tarefa é assegurar uma política econômica que fortaleça o mercado (TOURAINE, 2007, p. 28).

Para o que propomos aqui, interessa fazer uma pergunta metodológica: por que a modernidade contribui para o aparecimento e fortalecimento do pluralismo religioso? Para responder a essa pergunta, seguimos as intuições de Peter L. Berger \& Thomas Luckmann.

A preocupação de Berger \& Luckmann em Modernidade, pluralismo e crise de sentido (2012), foi diagnosticar e procurar entender o que orienta o humano marcado pela modernidade. Interessam aqui suas intuições, porque o que propomos é pensar o pluralismo religioso e as reais condições para um diálogo inter-religioso a partir do sujeito, tema desenvolvido por Touraine. Assim, Berger \& Luckmann elegem o sentido como base para suas constatações e provocações. Colocar o sentido como um elemento primário para uma discussão sociológica já é, per si, algo interessante, principalmente vindo de dois sociólogos de destaque. O sentido é trabalhado no campo filosófico e seus efeitos são analisados pela psicologia. No texto em questão, Berger \& Luckmann procuram fazer um trabalho transdisciplinar, principalmente quando definem "sentido" como "a consciência de que existe uma relação entre as experiências". Aqui, nossos autores focam no aspecto subjetivo do humano, estabelecendo, assim, um ponto fundamental para sustentar a pluralidade: "Vivências puramente subjetivas são o fundamento da constituição do sentido: estratos mais simples de sentido podem surgir na experiência subjetiva de uma pessoa" (BERGER \& LUCKMANN, 2012, p. 17).

Outrora, as instituições tutelavam o sentido, ou seja, exerciam a função social de regular o sentido. Agora, há concorrência quanto à oferta de sentido, provocando a escolha dentre as opções de sentido. Berger \& Luckmann chamam esses processos de "fornecedores de sentido para obter o favor de um público que se vê confrontado com a dificuldade de escolher, entre uma infinidade de ofertas, a mais adequada" (2012, p. 22-23). As instituições produtoras de sentido - e aqui pensamos nas religiões - estão diante de uma pluralidade que tem como marca a concorrência de bens simbólicos. Essa concorrência está atestada entre as religiões, mesmo considerando o elemento transcendental do discurso religioso. Isso ocorre porque as religiões não exercem mais o do- 
mínio incondicional sobre o humano. Dessa forma, não é possível uma prática religiosa ser imposta de maneira obrigatória, uma vez que há uma oferta de sistemas similares concorrendo entre si. As instituições religiosas, portanto, não poderiam ter a pretensão de totalidade, porque há outras "grandes" instituições que concorrem com elas. Assim, não seria mais possível um sistema totalizador, uma vez que "esta pretensão é refutada pelo sentido objetivo dos esquemas de ação das outras 'grandes' instituições” (BERGER \& LUCKMANN, 2012, p. 35). Com isso, é possível perceber que são as experiências religiosas a fornecer condições para que o pluralismo religioso seja dinâmico e perceptível. Nas palavras de Berger e Luckmann, "o pluralismo moderno leva a um enorme relativismo dos sistemas de valores e da interpretação. Em outras palavras: os antigos sistemas de valores e de interpretação são descanonizados" (2012, p. 52). Se, por um lado, a pluralidade causa crise de sentido, por outro, oferece uma considerável diversidade de sentido, e aqui pensamos em experiências religiosas. Com isso, as experiências religiosas tornam-se híbridas. Essa constatação é perfeitamente perceptível no contexto religioso brasileiro, por exemplo. Assim, a religião, como instituição, perde cada vez mais a sua centralidade, enquanto mediadora de experiências religiosas, e novas formas de se experimentar o sagrado ganham outras configurações. Maria Clara L. Bingemer, comentando sobre esse processo, diz que "a era da religião como estrutura está terminada, embora não como cultura. A religião perdeu sua função social, embora talvez não sua função subjetiva" (1993, p. 29). A subjetividade é marca indelével da contemporaneidade e esse dado precisa ser levado em consideração quando o tema é multiplicidade de oferta de bens religiosos e pluralismo religioso. Com isso, Bingemer pontua: "A sociedade moderna talvez não seja uma sociedade sem religião, mas é uma sociedade que se constitui em suas articulações principais pela 'metabolização' da função religiosa” (1993, p. 29). Essa metabolização, ou seja, a capacidade de transformar algo que, por alguma razão, foi rejeitado, em outra coisa, é uma característica evidente de uma sociedade que soube lidar com ou assimilou a oferta de bens religiosos. Essa característica que Bingemer sinaliza é que permite certa independência do sistema religioso organizado e a possibilidade de bricolagem na construção das experiências religiosas, ou seja, alguém que configura sua experiência religiosa, quando a dupla pertença passa a ser um agregador comum.

É fato que a religião se tornou intimista. Por isso a concorrência entre os mediadores do sagrado. Uma vez que as instituições religiosas perdem espaço, a procura por experiências religiosas sem vínculo institucional será crescente: "Todas as pesquisam mostram a perda da autoridade vinculante das instituições religiosas e a maior autonomia dos indivíduos na montagem 
dos seus próprios sistemas religiosos. Isso implica crise das instâncias estabelecidas de intermediação religiosa" (MOREIRA, 2008, p. 29). A capacidade de leitura simbólica de diferentes ramificações religiosas é notória. Diversas pessoas estão configurando seu mapa religioso tendo como referência não mais doutrinas, ritos ou estruturas estabelecidas e organizadas, mas aspectos subjetivos. Há um trânsito entre pertenças religiosas que possibilita uma impermanência em determinada moldura institucional. Essa característica não significa, portanto, afastamento da religião. Pelo contrário, favorece o pluralismo religioso e a dupla pertença, porque "as instituições tradicionais produtoras de sentido têm se deparado com a precariedade do engajamento das pessoas com o seu sistema de crenças" (SOUZA, 2001, p. 159).

\section{Pluralismo religioso e diálogo inter-religioso}

Partindo do pressuposto de que há uma crise institucional da religião e que esse fato não significa, paradoxalmente, retração da religião no contexto social, procuramos tratar do pluralismo religioso como uma consequência da secularização e averiguar as possibilidades de diálogo inter-religioso. Com isso, queremos responder à seguinte pergunta: a partir da constatação da crise das instituições que operacionalizam a religião, e tendo o pluralismo religioso como fato, há possibilidades de diálogo inter-religioso? É uma pergunta metodológica que fazemos aqui, porque estão em curso propostas de diálogo inter-religioso a partir da constatação do pluralismo religioso, principalmente entre pesquisadores de tradição católica, envolvendo a teologia. A questão que levantamos não se dá, precisamente, em torno do aspecto doutrinário, tema tratado pela Igreja Católica, por exemplo, em seus documentos, a partir do Concílio Vaticano II, e que são objeto de estudo de teólogos que tratam do tema do pluralismo religioso. Se estamos advogando que as instituições estão em crise quanto à mediação de bens religiosos e seu discurso transcendental, perguntamos se poderia haver outra via para o diálogo inter-religioso, uma vez que, a nosso ver, os meios institucionais não dão conta, precisamente, da diversidade e dinâmica religiosa, principalmente no Brasil, por exemplo. Por essa razão, é possível dizer que o pluralismo religioso ultrapassa os limites da tradição na compreensão da religião (SANCHEZ, 2005, p. 37). Mesmo admitindo que o pluralismo religioso seja um campo dominado por cristãos que o pensam a partir de certo inclusivismo teológico (TROCH, 2010, p. 133), ainda assim não se anula o fato de ser algo dado com o advento da modernidade, ou seja, o pluralismo não surge com a teologia; ele é tratado, também, pela teologia. Portanto, o pluralismo religioso, antes de qualquer coisa, se constitui a partir de uma "busca de sentido para a vida, preferencialmente 
no aspecto prático; uma vez mediado pelas ofertas de bens simbólicos, possibilita diferentes opções religiosas" (RIBEIRO, 2014, p. 28). Enquanto há o debate, legítimo, em torno de aspectos doutrinários a partir do pluralismo religioso, a religião acontece à margem dessas questões também. O que estamos dizendo é que o pluralismo religioso está para além do aspecto doutrinário ou teológico, embora esses dois aspectos tenham sua importância em determinados ambientes.

Enquanto teólogos discutem os modelos teológicos que sejam mais adequados para se pensar o pluralismo religioso, há pesquisadores que dão outra direção para o debate, porque entendem que "o futuro aponta para uma sociedade com pluralidade de ofertas religiosas, provavelmente sem uma instituição que detenha o poder simbólico" (MOREIRA, 2008a, p. 74). É nesse sentido que entendemos ser viável uma concepção de interação religiosa sem, necessariamente, passar pelas fontes institucionais. A nosso ver, as instituições estão aí, mas não exercem fator decisivo e totalizador na vida religiosa das pessoas, o que favorece a dupla pertença, como também iniciativas individuais e coletivas que não são, necessariamente, legitimadas pela instituição religiosa pertencente. Os estudos de Alberto da Silva Moreira seguem nessa direção. Para ele, há um deslocamento do religioso e isso modificou a influência pública ou ideológica da religião institucionalizada. Como estamos sinalizando desde o início desse texto, Moreira constata que "outras instituições produtoras de interpretação e sentido se beneficiam da crise institucional da religião" (2008a, p. 75). Isso, indubitavelmente, causa transtornos nas instituições religiosas produtoras de sentido, porque o discurso transcendental de uma determinada instituição religiosa já não tem o mesmo efeito e, portanto, sofre com a concorrência. Em outro momento, Moreira investiga as consequências da globalização para as religiões e constata algo interessante: "Todas as pesquisas mostram a perda da autoridade vinculante das instituições religiosas e a maior autonomia dos indivíduos na montagem dos seus próprios sistemas religiosos" (2008, p. 29). Compreendemos, então, que uma discussão em torno do pluralismo religioso precisa levar em consideração esse quadro, principalmente quando a religião não está, precisamente, "nas igrejas, templos e terreiros, onde ela se tematiza explicitamente, mas também lá onde ela não se chama religião" (MOREIRA, 2008, p. 30). Essa dinâmica religiosa favorece a fluidez do ser religioso e as instituições religiosas não têm condições de deter essa dinâmica. Dinâmica que vem crescendo com o deslocamento do religioso, contexto no qual as instituições do depósito simbólico de bens religiosos não têm mais primazia: "A religião se tornou cada vez mais um objeto flutuante, desprovido de toda ancoragem social (...) 
em instituições estabelecidas. Em lugar - dessas instituições - surgiu uma rede (...) difusa e desprovida de centro, conectada por afiliações genéricas, multidirecional e abstrata" (GEERTZ, 2006).

No Brasil, o pluralismo religioso é um patrimônio cultural. A diversidade religiosa é patente. A presença da religião se dá em diferentes modalidades, mas, infelizmente, casos de intolerância e discriminação, por conta da preferência religiosa, ainda ocorrem. Excetuando isso, autores constatam o deslocamento do religioso na sociedade brasileira e a crescente diminuição das instituições religiosas produtoras de sentido na formatação religiosa de uma parcela significativa da população. Estudos feitos a partir dos censos do IBGE entre os anos de 2000 e 2010 demonstram a pluralidade religiosa que o país possui, como também expressões religiosas desvinculadas de qualquer instituição - como é o caso dos "sem religião" - cujo percentual saltou de 7,3\% em 2000, para 8,0\%, em 2010. ${ }^{1}$ Ao que parece, essas proporções continuam em ascensão.

Quando nos ocupamos desse quadro no país, é possível verificar que a situação religiosa mudou drasticamente. Carlos Rodrigues Brandão, antropólogo que se dedica a estudar os contornos da religião no país, assegura que o campo religioso mudou "de uma situação de hegemonia para uma situação de mercado religioso" (1993, p. 81). Quando pensamos em mercado religioso, referimo-nos à oferta religiosa e, se há oferta religiosa, há "consumidores" da religião. Em outro texto, Brandão faz uma importante constatação, ou seja, que há uma "crise das instituições tradicionais produtoras de sentido" (1994, p. 23). No tocante aos sujeitos, Brandão conclui que, a partir dessa crise institucional, eles transitam "entre sistemas oficiais e alternativos, religiosos, eclesiásticos, de pequena confraria confessante ou absolutamente solitários” (1994, p. 31). Com isso, é possível dizer que o pluralismo religioso não se dá, exclusivamente, entre religiões com seus aparatos institucionais. Antes, esse pluralismo religioso é marcado pela pluralidade, no sentido de ter um "caráter mais valorativo" (RIBEIRO, 2014, p. 20), ou seja, as diferenças religiosas são minimizadas e as semelhanças são realçadas. Assim, é possível haver partilhas e convergências em torno de temas/questões comuns por parte de pessoas/grupos com suas diferenças religiosas. Isso não aconteceria de maneira mais eficaz, a nosso ver, quando se está lidando com instituições religiosas que, com algumas exceções, não "abrem mão" de seus sistemas que são, geralmente, mais enrijecidos. Aqui residiria o diálogo inter-religioso, ou seja, um diálogo entre

\footnotetext{
Recomendamos, aqui, os textos organizados por Faustino TEIXEIRA \& Renata MENEZES: As religiões no Brasil: continuidades e rupturas. $2^{\mathrm{a}}$ ed. Petrópolis: Vozes, 2011; Religiões em movimento: o censo de 2010. Petrópolis: Vozes, 2013.
} 
sujeitos de fé. Desse modo, haveria espaço para maior interação entre pessoas com suas pertenças religiosas que não estão, necessariamente, vinculadas a uma instituição religiosa. À pergunta que fizemos - a partir da constatação da crise das instituições que operacionalizam a religião, e tendo o pluralismo religioso como fato, há possibilidades de diálogo inter-religioso? - entendemos ser possível responder afirmativamente. Mesmo a religião tendo o seu caráter individualista por um lado, com uma forte tendência ao mercado e, por outro lado, um apelo mais fundamentalista de setores conservadores, ainda assim é possível visualizar um horizonte de diálogo. Isso se dá porque as religiões têm um patrimônio que, além de espiritual e cultural, é ético também. Dessa forma, a religião tem como caminho uma vivência de "solidariedade e mutualidade, em abertura ao outro e em comunicabilidade harmoniosa e respeitosa entre os seres humanos, em desapego às tradições cristalizadas, a fim de construir um mundo a partir de pessoas, grupos e instituições de boa vontade" (RIBEIRO, 2014, p. 21). Como o universo religioso é plural, há espaço para formulações conjuntas e diretivas em torno de temas que afetam a todos. O que estamos tentando defender é que pessoas de fé não estão apenas preocupadas em configurar seu "mundo" religioso dentro de um mercado religioso que oferece bens simbólicos e múltiplas pertenças, mas estão também interessadas em elaborar sínteses que sejam capazes de interagir a partir das diferenças religiosas, com o fim de proporcionar melhores condições de vida, principalmente quando a vida está ameaça em sua dignidade.

Claudio Ribeiro, por exemplo, oferece uma dessas sínteses quando trata do pluralismo religioso, da democracia e dos direitos humanos. Para o pesquisador, grupos religiosos de diferentes pertenças fortalecem a democracia e a luta pelos direitos humanos, quando interagem em perspectivas ecumênicas e inter-religiosas. Em um de seus trabalhos, ele analisou organismos que atuam no Brasil $^{2}$ e que procuram ser catalizadores de projetos que agregam a diversidade religiosa do país com as demandas sociais, políticas e econômicas. A partir dessas demandas, espera-se que o diálogo inter-religioso forneça elementos para o "combate aos racismos, ao sexismo e ao homofobismo e a crítica ao sistema capitalista como produtor de desigualdades sociais, violência e pobreza" (RIBEIRO, 2016, p. 208). O diálogo inter-religioso se daria, não obstante o aspecto subjetivo da religião, em torno de temas comuns à vida,

2 Os organismos que Claudio Ribeiro listou em seu trabalho são: Comitê Inter-religioso do Estado do Pará (CIEPA); Encontro da Nova Consciência (Campina Grande/PB); Fórum Inter-religioso do Recife/ PE; Comissão de Combate à Intolerância Religiosa (CCIR - Rio de Janeiro/RJ); Casa das Religiões Unidas (São Paulo e Rio de Janeiro); Fórum Nacional Permanente do Ensino Religioso (FONAPER); Koinonia - Presença Ecumênica \& Serviço; Centro Ecumênico de Serviço à Evangelização e à Educação Popular (CESEEP); Rede Ecumênica da Juventude (REJU). 
seja no cotidiano das pessoas, seja na vida política, social e econômica de uma localidade.

Interessa-nos, agora, trazer as contribuições de Alain Touraine, no que concerne ao sujeito. A nossa intenção é demonstrar o lugar do sujeito, conforme Touraine, nesse processo que pontuamos até aqui entre pluralismo religioso e diálogo inter-religioso. Entendemos que as teses do pensador francês poderão ajudar na construção de uma concepção que abrigue uma leitura do mundo secularizado e o pluralismo religioso, além de trazer alguns insights para o que propomos, ou seja: tentar dizer qual o lugar do sujeito diante de um quadro onde as instituições religiosas não exercem mais um domínio totalizador e tem como fator preponderante o pluralismo religioso, mas, também, deseja ser - tal sujeito - elemento de diálogo e interação, a partir do contexto em torno de temas que afetam a vida. A pergunta que nos propomos é sobre a possibilidade de indicar caminhos que tenham o sujeito como protagonista nesse processo. Para isso, entendemos que as reflexões de Touraine possam iluminar o trajeto.

\section{O sujeito: emancipado e religioso}

Alain Touraine é um pensador conhecido no Brasil. Suas principais obras foram traduzidas no país e suas ideias são reproduzidas em trabalhos acadêmicos. Aqui, destacamos duas obras do autor: Crítica da modernidade e Um novo paradigma: para compreender o mundo de hoje. Nessas duas obras, entendemos que o autor aborda de maneira sistemática a sua concepção de sujeito.

Começamos por observar a obra Um novo paradigma, por entender que, nesse texto, o pensador francês faz uma análise relacionada à "mudança de paradigmas", termo popularizado por Thomas Kuhn. Logo no início, Touraine faz uma síntese: "Dois séculos após o triunfo da economia sobre a política (...) precisamos de um novo paradigma" (2007, p. 9). A sua discussão se dá a partir de um novo paradigma e, para isso, nosso autor passa pelas grandes transformações do mundo, chegando à conclusão que considera fundamental: a modernidade favoreceu o surgimento do indivíduo. Apontando todos os problemas que a modernidade agrega, o autor conclui que cabe à modernidade "reconstruir instituições que não estarão mais a serviço da sociedade, rebatizada como 'interesse social' ou 'bem comum', mas a serviço da liberdade criadora de cada indivíduo" (TOURAINE, 2007, p. 93). Ressaltando os problemas que essa premissa acarreta, o autor prega o fim do pensamento social e o começo do individualismo libertador. Aqui, a subjetividade ganha espaço. Agora, "o indivíduo, enquanto moderno, escapa, portanto, aos determinismos sociais, na medida em que é um sujeito autocriador" (TOURAINE, 2007, p. 
103). Com a concepção de sujeito, o autor propaga a completa autonomia do eu. Uma vez descontruídos discursos e sistemas que aprisionam o indivíduo, o sujeito se torna ator social capaz de configurar a sua realidade e determinar as suas preferências e escolhas. Por essa razão, "o sujeito não é apenas aquele que diz 'eu', mas aquele que tem consciência de seu direito de dizer 'eu" (TOURAINE, 2007, p. 113). O que entra, aqui, nessa configuração do sujeito, é a reivindicação dos direitos, sejam eles civis, sociais, culturais e humanos. O sujeito tem autonomia quando munido de direitos, tema que Touraine se dedica a pensar (2007, p. 114).

Quem é o sujeito? Como se dá o processo emancipatório? Na segunda parte da obra Um novo paradigma, Touraine responde a essas questões. Para ele, "o sujeito se forma na vontade de escapar às forças, às regras, aos poderes que nos impedem de sermos nós mesmos, que procuram reduzir-nos ao estado de componente de seu sistema e de seu controle sobre a atividade, as intenções e as interações de todos" (2007, p. 119). O sujeito toma as rédeas de sua própria história. Não mais dominado por "poderes" exteriores, mas consciente do seu lugar no mundo, o sujeito é sempre "rebelde, dividido entre raiva e esperança" (TOURAINE, 2007, p. 119). Desse modo, o sujeito, para Touraine, está em luta, porque, para ele, “o sujeito é um chamamento a si mesmo, uma vontade de retorno a si mesmo (...) o sujeito evoca uma luta social como a de consciência de classe" (2007, p. 120). O sujeito é um ator social que ganhou independência jurídica e política. Não é um indivíduo subjugado ao sistema, mas, antes, é um sujeito que fez a leitura correta do sistema e não se deixa mais vencer por ele. É a maioridade diante de sistemas totalizadores. O que está em jogo é os direitos, uma das fontes do sujeito.

\section{Qual a relação do sujeito com a religião?}

Antes de entrar na relação sujeito e religião em Touraine, interessa observar que o autor está muito próximo do que estamos pontuando até agora, ou seja: "para o autor, a secularização não é o fim da religião, mas a autonomia da organização da vida em relação a ela" (BARRERA RIVERA, 2001, p. 194). Ele não recusa a presença (ou participação) da religião na configuração do sujeito, pelo contrário, "o sujeito (...) não é uma figura secularizada da alma, a presença de uma realidade sobre-humana, divina ou comunitária, em cada indivíduo" (TOURAINE, 2007, p. 127). Com isso, perguntamos pela função da religião na configuração do sujeito, principalmente porque o autor faz uma crítica à modernidade, quando esta identifica o ator social com a sua produção, "matando", portanto, o sujeito: "A ideologia modernista afirma a morte do sujeito porque a corrente dominante do pensamento ocidental, desde o século 
XVI até hoje, foi materialista” (BARRERA RIVERA, 2001, p. 195). Touraine não deixa a religião fora da configuração do sujeito, porque a modernidade desencantou o mundo com a razão, mas não conseguiu suprimir o sagrado nesse processo. Se a questão cultural é um elemento central na configuração do sujeito, a religião tem o seu lugar para o autor. Para Barrera Rivera, o que Touraine propõe é uma "interpretação da autonomia dos sujeitos religiosos contemporâneos - ou da incapacidade das instituições reguladoras da sociedade - como expressão de uma liberdade de escolha inédita do indivíduo contemporâneo, em todos os campos da vida" (2001, p. 196).

A religião está presente como um elemento constitutivo do sujeito. Em Crítica da modernidade, ele diz: "É preciso recusar abertamente a ideia da ruptura entre as trevas da religião e as luzes da modernidade, pois o sujeito da modernidade não é outro senão o descendente secularizado do sujeito da religião" (TOURAINE, 1994, p. 253). Uma vez o sujeito tendo como elemento agregador a religião, ela - a religião - tem o seu lugar/papel nos desdobramentos em que o sujeito está envolvido. O que significa dizer que, para Touraine, na conjuntura da modernidade "nada autoriza a deitar fora o sujeito com a religião" (1994, p. 253). O sujeito é emancipado das regras e determinações que a modernidade fez enxergar e sair, mas continua sendo religioso, com as devidas proporções.

Touraine entende que a modernidade não substituiu o pensamento religioso pela racionalidade instrumental e pela secularização. Mesmo com o "enfraquecimento das instituições religiosas e a afirmação de expressões menos institucionalizadas do sentimento religioso" (2007, p. 151-152). Isto sugere que o sagrado ainda mantém o seu espaço, mesmo sem a sacralização da sociedade. O que ocorre é que "o sagrado agarra-se, portanto, novamente às comunidades". O sujeito emancipado também é o sujeito religioso. Nesse sentido, o sujeito tem, na religião, um meio de se afirmar frente a situações de desagregação, promovidas pela modernidade e seu programa pautado no progresso. Isso não significa o regresso da influência da Igreja, como mediadora institucional de produção de sentido, mas a autonomia do sujeito, que tem na religião o meio de superação de forças contrárias ou danosas para a autonomia do sujeito. Nas palavras de Touraine: "É porque a secularização está solidamente instalada que se torna possível reconhecer na tradição religiosa uma referência ao sujeito que pode ser mobilizada contra o poder dos aparelhos econômicos, políticos e midiáticos" (1994, p. 254). Para o autor, está dado o lugar da religião na configuração do sujeito. Esse sujeito, emancipado e rebelde, também é religioso, porque vê na religião uma maneira de afirmação diante de propostas que fracassaram no decorrer do caminho, 
principalmente quando essas propostas prometeram bem-estar ao humano, mas falharam ao elaborar e executar sistemas que passaram a se alimentar da inumanidade da vida, como o sistema de mercado, por exemplo.

A partir dessa primeira leitura em Alain Touraine, perguntamos: qual a possível relação entre o sujeito e o diálogo inter-religioso? Partindo do pressuposto de que a dinâmica religiosa está para além das instituições religiosas produtoras de sentido, a concepção de sujeito em Touraine poderia contribuir para o fortalecimento do diálogo inter-religioso? Havendo razões para contestação e participação em movimentos que visam os direitos culturais e sociais, ou seja, "o direito de ser sujeito é o direito que cada um tem de combinar sua participação na atividade econômica com o exercício de seus direitos culturais, no quadro do reconhecimento dos outros como sujeitos" (TOURAINE, 2007, p. 114), entendemos que a contribuição de Touraine poderia favorecer a compreensão de diálogo inter-religioso, por ser o sujeito um ator social que não está massificado, nutrindo a capacidade de resistir e lutar, mesmo sabendo que "estas lutas contra o que nos priva do sentido de nossa existência são sempre lutas desiguais com um poder, contra uma ordem" (TOURAINE, 2007, p. 115). Esse sujeito dialógico resiste à insistência de subjugação ao poder dominante, principalmente em sua face econômica e massificada. O sujeito não aceita a condição de vida que lhe é imposta. Antes, é instrumento de liberdade, porque "não há sujeito senão rebelde, dividido entre a raiva contra o que ele sofre e a esperança da existência livre, da construção de si mesmo - que é sua preocupação constante" (TOURAINE, 2007, p. 115).

Nas pegadas de Touraine, quanto ao aspecto do sujeito enquanto ator social, entendemos que há possibilidade de convergir essa concepção de sujeito com o entendimento de diálogo inter-religioso desenvolvido pelo teólogo Jürgen Moltmann. Quando formulamos uma proposta que procura pensar o pluralismo religioso, o diálogo inter-religioso e o lugar do sujeito nesse processo, privilegiaremos a contribuição de um teólogo que enfoque atores de diálogo - e não, necessariamente, instituições religiosas - em torno de temas comuns à vida. Optamos, neste ponto, por Moltmann, por ele produzir uma teologia das religiões de caráter ecumênico (no sentido de "casa comum"), com uma forte resistência a setores da sociedade que procuram promover a desintegração do bumano e suas necessidades vitais para a vida.

\section{O lugar do diálogo inter-religioso}

A concepção de Moltmann no tocante ao diálogo inter-religioso manifesta-se em duas percepções: (i) a capacidade para o diálogo e (ii) a dignidade para o diálogo. No primeiro caso, cientistas da religião estão capacitados para o diálogo, 
por olharem as religiões de maneira objetiva. Mas a dignidade para o diálogo acontece quando há "uma posição firme na sua própria religião e se vai para o diálogo com a autoconsciência correspondente. Somente a domiciliação ${ }^{3}$ na sua própria religião capacita para o encontro com uma outra (religião)" (2004, p. 28). É aqui que reside a crítica de Moltmann ao pluralismo, quando entendido a partir da relativização. ${ }^{4}$ Para Moltmann, não há interesse em conversar com relativizadores da religião. Se pluralismo for concebido como pressuposto para a relativização das religiões, logo "o pluralismo (...) não se constitui numa teoria particularmente útil para o diálogo inter-religioso" (2004, p. 29). Dito de outra forma, para Moltmann não há interesse em alocar as religiões em paradigmas como exclusivismo, inclusivismo ou pluralismo. Essa discussão não contribui, porque o pressuposto para o diálogo é a "verdade da sua religião". No diálogo, segundo Moltmann, não é possível o consenso, pois ele, o consenso, não é o objetivo do diálogo, até porque "se um dos parceiros for convencido pelo outro, acaba o diálogo" (2004, p. 29). Para Moltmann, a discussão teológica entre as religiões pode até ser benéfica, mas não ajuda, de maneira efetiva, no processo do diálogo inter-religioso. Não há, por parte de Moltmann, maior interesse nesse aspecto do diálogo inter-religioso. O que há é a emergência em outro campo que, no seu entender, é premente e irremediável. Trata-se de um diálogo necessário, ou seja, ele se torna necessário, "quando surge um conflito que ameaça a vida, e cuja solução pacífica deve ser buscada conjuntamente mediante o diálogo" (2004, p. 29).

Em sua compreensão do diálogo inter-religioso, Moltmann faz duas distinções: ele se dá de maneira direta e indireta. No primeiro caso, o diálogo se dá como discussão teológica, na qual as questões que envolvem as interpretações das religiões em relação ao transcendente e a salvação estão em pauta. Como afirmamos, Moltmann não desconsidera esse aspecto do diálogo inter-religioso, mas não há interesse de sua parte em ampliar essa perspectiva. Nessa vertente, há importantes teólogos fazendo um profícuo trabalho. Entre eles, destacam-se Paul F. Knitter e Jacques Dupuis, no campo católico. Entre os protestantes, John Hick se notabiliza. No Brasil, o nome de Mário de França Miranda adquire importância quando procura articular, teologicamente, as religiões com o cristianismo. ${ }^{5}$ Esse é o diálogo que Moltmann considera direto e que tem, naturalmente, suas dificuldades, principalmente com as religiões misticas e as religiões naturais, uma vez que "as religiões do livro estão melhor

\footnotetext{
3 A dupla pertença religiosa não é levada em consideração por Moltmann.

4 Ideia de que todas as religiões são iguais, desconsiderando as especificidades das religiões e suas devidas ênfases.

5 Recomendamos o texto para melhor aprofundamento nessa perspectiva: MIRANDA, Mário de França. O cristianismo em face das religiões. São Paulo: Loyola, 1998.
} 
preparadas para diálogos verbais e argumentações lógicas do que as religiões meditativas e as religiões rituais" (2004, p. 30). Quanto ao aspecto místico das religiões orientais, Faustino Teixeira vem dando uma importante contribuição, demonstrando pontos de diálogo com essas expressões religiosas. ${ }^{6}$

Quanto ao diálogo indireto, Moltmann tem maior interesse. Esse diálogo se dá em "nível local sobre questões sociais e no nível mundial sobre questões ecológicas" (2004, p. 30). Esse diálogo é proveitoso porque não está se "falando sobre nós mesmos ou uns sobre os outros, mas conjuntamente sobre um terceiro assunto" (2004, p. 30). O assunto, nesse diálogo, está permeado por temas como a paz e as questões ecológicas, mas também econômicas. Aqui, para Moltmann, as religiões consideradas primitivas ou naturais podem participar mais efetivamente, "pois elas preservam muita sabedoria social e ecológica" (2004, p. 30).

Moltmann faz o apelo por paz entre as religiões, uma vez que "não sopra atualmente um vento de paz" (2008, p. 35). O pressuposto fundamental para as religiões é a paz, porque somente a partir dela será possível concentrar forças em temas comuns ao mundo: "se as religiões mundiais quiserem realmente servir à vida do mundo, elas mesmas precisam primeiro ser capazes de viver a paz" (2008, p. 35-36). É aqui que Moltmann alude a um critério para as religiões quando entende que "a paz consiste politicamente na presença da justiça, não apenas na ausência de violência” (2012, p. 195).

Uma teologia ecumênica das religiões, para Moltmann, se faz em torno de problemas que afetam a todos; tem caráter pluralista, ou seja, "a aproximação, o diálogo e as ações inter-religiosas são elementos promotores do reino de Deus, de sua justiça e da paz mundial. O principal teólogo protestante que se relaciona com esta ênfase é Jürgen Moltmann" (CUNHA, 2007, p. 44). Sendo assim, Moltmann concebe um pluralismo que seja também particularista, ou seja, mantém uma tensão entre esses dois polos.

A sua contribuição teológica se torna relevante, principalmente pelo fato dele ser notadamente reconhecido como um teólogo que procura pensar o futuro e os caminhos para ele, com reflexões que contemplam aberturas e integrações a partir da esperança, categoria fundamental na produção teológica do autor.

O diálogo que Moltmann propõe se dá em torno de pessoas com suas religiões, ou seja, ele concorda com a necessidade do diálogo, mas não está em busca de uma síntese religiosa. Pelo contrário, para Moltmann, cada religião, com seus limites e respectiva tradição, é chamada a dialogar. Por isso, não se trata de algo que transponha a religião, mas entre pessoas e suas religiões. Para esse diálogo acontecer, as pessoas devem se encontrar no espaço

Recomendamos aqui: TEIXEIRA, Faustino. Religiōes \& espiritualidades. São Paulo: Fonte Editorial, 2014. 
religioso de cada uma delas, a fim de buscar pontos de contato, a partir de sua própria tradição e, sem deixá-la, convergir para problemas comuns. Aqui pontuamos o pluralismo particularista de Moltmann, que admite a realidade das religiões e suas tradições, mas entra no diálogo com suas categorias teológicas particulares, respeitando, igualmente, as particularidades da religião do outro. Para o teólogo de Tübingen, o cenário mundial suscita o diálogo em diferentes áreas e com a religião não poderia ser diferente.

Diante da necessidade do diálogo, Moltmann concebe os problemas comuns à vida. Em sua teologia, predomina a abertura ao outro, participando, assim, dos sofrimentos do povo, propondo caminhos de esperança. Em sua reflexão teológica, há um chamamento para essa abertura ao mundo com comprometimento e solidariedade. Assim, os temas da teologia são articulados de maneira ecumênica.

\section{Sujeito e diálogo inter-religioso: possibilidades}

Propomo-nos, agora, a articular as concepções relativas ao sujeito e à abertura para o diálogo inter-religioso, tendo como quadro maior o que elencamos acima, quando tratamos das instituições religiosas e o processo de secularização. Ocupar-nos-emos das possibilidades do diálogo inter-religioso a partir das percepções de Moltmann, procurando alinhar essas percepções com a ideia de sujeito em Touraine, com ressonância na América Latina. Entendemos que seja possível apontar caminhos para esse trajeto buscando o lugar do sujeito nesse processo. Para isso, trazemos as contribuições de Moltmann, que nos servirão para trabalhar temas ligados ao sujeito desenvolvido por Touraine, além de focar no contexto latino-americano.

O sujeito é um conceito trabalhado no contexto latino-americano. Sendo a América Latina um continente que ainda abriga contradições sociais, o sujeito se constitui elemento de resistência e luta, principalmente quando as diferenças econômicas são patentes. Na mesma direção de Touraine, o sujeito não está aí para ser objetivável: "Ser sujeito anterior a toda e qualquer institucionalização que a objetifica em um papel social” (SUNG, 2002, p. 62). Antes, o sujeito, assim como para Touraine, "se manifesta na resistência às formas concretas de dominação" (SUNG, 2002, p. 62). Considerando as forças políticas que operam no contexto latino-americano, o sujeito é configurado para ser ator social nesse processo. Para esse fim, como bem observa Jung Mo Sung, é preciso canalizar a resistência e a luta que o sujeito se propõe a fazer (2002, p. 63). Nesse aspecto, os movimentos sociais são ferramentas de resistência e a religião, como grupo social, poderá ser elemento de resistência na luta contra instituições que oprimem. 
As religiões exercem uma expressiva influência na realidade latino-americana. Esse é um fato inconteste, mesmo com o advento da secularização, que insistiu em diminuir o papel da religião no contexto social. O que se demonstrou foi que a religião "nos últimos anos, mostrou-se relevante nos acontecimentos e processos sociais” (RIBEIRO, 2014, p. 116). A dimensão ética da religião favorece esse enquadramento. Touraine, por exemplo, entende que a dimensão ética da religião não deve ser rejeitada pelo sujeito, principalmente quando o sujeito está lutando por direitos: "A exigência moral passou da religião para aquilo a que se chama ética, mas esta pode encontrar, nas tradições religiosas, referências ao sujeito que a nossa cultura secularizada não deve rejeitar" (1994, p. 254).

Como pontuamos acima, Moltmann trata o diálogo inter-religioso de maneira indireta, ou seja, sendo praticado por agentes de fé (por isso entendemos ser o diálogo entre fés e não, precisamente, entre religiões, mas, sim, entre sujeitos que tem religião). A dimensão ética é um aspecto importante do diálogo inter-religioso. No nosso entender, esta dimensão se constitui premente e anterior a qualquer posicionamento teológico ou doutrinário. A "indignação ética nasce do reconhecimento da humanidade da pessoa que está sendo negada" (SUNG, 2002, p. 55). Esse fato suscita movimento e resistência. Nesse sentido, o diálogo inter-religioso precisa priorizar a dimensão ética da religião. Não que as outras dimensões não tenham a sua importância, mas aquela - ou seja, a dimensão ética - se mostra imprescindível em um contexto de negação. O sujeito, portanto, é ator social quando diante da condição do que não se é. Aí reside o diálogo inter-religioso: quando o sujeito se transforma em ator social e faz resistência a todas as formas de desintegração do bumano: "O diálogo inter-religioso deve contemplar as formas de serviço e compaixão com o sofrimento humano e as ações e manifestações públicas de protesto e contestação da injustiça social" (RIBEIRO, 2016, p. 22). Em diálogo, as religiões podem promover a justiça, tendo o princípio ético do cuidado para com o outro e com o meio ambiente. O cristianismo, por exemplo, tem em Jesus o seu maior exemplo de alguém que "se aplica aos doentes, não aos saudáveis; sua amizade abraçou os marginalizados, pecadores e coletores de impostos; ele estava com os perdidos, não com os bons" (MOLTMANN, 2012, p. 214). A busca por justiça se dá em torno dos direitos humanos, econômico e ecológico. Os problemas que afetam a todos, como os danos ao meio ambiente, e os conflitos sociais e econômicos, serão mediados pela justiça. A justiça seria o meio pelo qual as religiões buscariam consenso na luta pelos "direitos humanos e os direitos da natureza" (MOLTMANN, 2012, p. 255). Em consonância com isso, Touraine alerta: "Nossa capacidade de criar, de transformar e de 
destruir nossa vida e nosso meio ambiente nos obriga a voltar nosso olhar, fixado por tanto tempo na natureza e nos instrumentos que nos permitiram conquistá-la, para nós mesmos" (2007, p. 211).

Esse caminho se torna possível com o sujeito sendo ator social e a religião com sua dimensão ética em colaboração. Mas ele não é um caminho fácil. Portanto, poderá ser "em nível religioso, explícito ou não, em formas institucionais ou de caráter mais espontâneo" (RIBEIRO, 2016, p. 22).

As religiões não podem se furtarem diante das tensões pelas quais o mundo passa, tais como: o fanatismo, o racismo, o terrorismo. $\mathrm{O}$ diálogo inter-religioso precisa acontecer, tendo, mais do que nunca, esses dilemas como foco. O atual cenário, que pode ser considerado pessimista, não dá sinais de melhoras quando os principais articuladores da condição humana são o Estado, a ciência e o sistema econômico. Eis o lócus do sujeito nesse processo.

\section{Referências bibliográficas}

BARRERA RIVERA, Paulo. Tradição, transmissão e emoção religiosa: sociologia do protestantismo contemporâneo na América Latina. São Bernardo do Campo: Olho d’Água, 2001.

BERGER, Peter L. \& LUCKMANN, Thomas. Modernidade, pluralismo e crise de sentido: a orientação do homem moderno. 3. ed. Petrópolis: Vozes, 2012.

BERGER, Peter. O dossel sagrado: elementos para uma teoria sociológica da religião. 3. ed. São Paulo: Paulus, 1985.

BINGEMER, Maria Clara L. Alteridade \& vulnerabilidade: experiência de Deus e pluralismo religioso no moderno em crise. São Paulo: Loyola, 1993.

BRANDÃO, Carlos Rodrigues. A crise das instituições tradicionais produtoras de sentido. In: MOREIRA, Alberto da Silva \& ZICMAN, Renée (Orgs.). Misticismo e novas religiões. Petrópolis: Vozes, 1994, p. 23-41.

BRANDÃO, Carlos Rodrigues. As muitas moradas: crenças e religiões no Brasil de hoje. In: BEOZZO, José Oscar (Org.). Curso de verão: ano VII. São Paulo: Paulus, 1993, p. 77106.

CUNHA, Magali do Nascimento. O pluralismo religioso na agenda das igrejas protestantes no mundo contemporâneo. In: BHOGAL, Inderjit. Pluralismo e a missão da igreja na atualidade. São Bernardo do Campo: Editeo, 2007, p. 25-46.

GEERTZ, Clifford. O futuro das religiões, Folha de S. Paulo, 14 de maio de 2006. Disponível em: http://www1.folha.uol.com.br/fsp/mais/fs1405200614.htm>. Acesso em: 21 abr. 2017.

LIBÂNIO, João Batista. O sagrado na pós-modernidade. In: CALIMAN, Cleto (Org.). A sedução do sagrado: o fenômeno religioso na virada do milênio. Petrópolis: Vozes, 1998, p. 61-78.

LIBÂNIO, João Batista. A religião no início do milênio. São Paulo: Loyola, 2002.

LOTT, Henrique. Religião, politica e democracia: a sociedade desencantada de Marcel Gauchet. São Paulo: Fonte Editorial, 2016. 
MOLTMANN, Jürgen. Ética da esperança. Petrópolis: Vozes, 2012.

MOLTMANN, Jürgen. Experiências de reflexão teológica: caminhos e formas da teologia cristã. São Leopoldo: Unisinos, 2004.

MOLTMANN, Jürgen. Vida, esperança e justiça: um testamento teológico para a América Latina. São Bernardo do Campo: Editeo, 2008.

MOREIRA, Alberto da Silva. "O deslocamento do religioso na sociedade contemporânea", Estudos de Religião, n. ${ }^{\circ}$ 34, p. 70-83, 2008 a.

MOREIRA, Alberto da Silva. O futuro da religião no mundo globalizado: painel de um debate. In: MOREIRA, Alberto da Silva \& OLIVEIRA, Irene Dias de (Orgs.). O futuro da religião na sociedade global: uma perspectiva multicultural. São Paulo: Paulinas, 2008, p. 17-35. RIBEIRO, Claudio de Oliveira. Caminhos plurais: quatro décadas de trajetos ecumênicos e pastorais. São Paulo: Reflexão, 2016.

RIBEIRO, Claudio de Oliveira. Pluralismo e libertação. São Paulo: Paulinas, 2014.

SANCHEZ, Wagner Lopes. Pluralismo religioso: as religiões no mundo atual. São Paulo: Paulinas, 2005.

SOUZA, Sandra Duarte. Trânsito religioso e construções simbólicas temporárias: uma bricolagem contínua, Estudos de Religião, São Bernardo do Campo, vol. 15, n. 20, p. 157-167, 2001.

SUNG, Jung Mo. Sujeito e sociedades complexas: para repensar os horizontes utópicos. Petrópolis: Vozes, 2002.

TEIXEIRA, Faustino. "A salvaguarda da diversidade e a defesa da criação", Horiz̧onte, vol. 13, n. ${ }^{\circ} 37$, p. 360-378, 2015.

TEIXEIRA, Faustino; MENEZES, Renata. As religiões no Brasil: continuidades e rupturas. 2. ed. Petrópolis: Vozes, 2011.

TOURAINE, Alain. Crítica da modernidade. Lisboa: Instituto Piaget, 1994.

TOURAINE, Alain. Um novo paradigma: para compreender o mundo de hoje. 3. ed. Petrópolis: Vozes, 2007.

TROCH, Lieve. No caminho da resistência e da compaixão: discursos dominantes e alternativos para o diálogo entre as religiões. In: MARQUES, Luiz Carlos (Org.). Religiosidades populares e multiculturalismo: intolerâncias, diálogos, interpretações. Recife: UFPE, 2010, p. 123-142.

Submetido em: 1-6-2017

Aceito em: 10-7-2017 